ISSN 0258-7122

Bangladesh J. Agril. Res. 34(1) : 15-24, March 2009

\title{
AGRO-ECONOMIC ANALYSIS OF MAIZE PRODUCTION IN BANGLADESH: A FARM LEVEL STUDY
}

\author{
MONLRUZZAMAN $^{1}$, M. S. RAHMAN ${ }^{2}$, M. K. KARIM ${ }^{3}$ AND Q. M. AlAM ${ }^{4}$
}

\begin{abstract}
The study was carried out in four major maize growing areas namely Chuadanga, Dinajpur, Bogra and Lalmonirhat during 2006-2007 to know profitability level of maize production in Bangladesh. A total of 200 randomly selected maize growers taking 50 from each location were interviewed using pre-designed interview schedule. The average yield was found to be $8.00 \mathrm{t} / \mathrm{ha}$. The average costs of maize production were Tk 44197, Tk 33195 and Tk 24441 per hectare on total cost, variable cost and cash cost basis respectively and gross return was Tk 69773 per hectare. The gross margin was Tk 36578/ha on total variable cost (TVC) and Tk 45332/ha on cash cost basis. The net return was observed to be Tk 25575 per hectare. Benefit cost ratios were calculated as 1.58, 2.10 and 2.85 on total cost, variable cost and cash cost basis respectively. As a result, maize cultivation was more profitable. Lack of capital and high price of TSP were the main constraints to its higher production.
\end{abstract}

Kew Words: Maize, production, agro-economic.

\section{Introduction}

Maize is one of the oldest and most important crop in the world. It is the highest yielding grain crop having multiple uses. The average yield of maize in 2003 in the world was 4.47 tons per hectare as compared to 2.67 and 3.84 tons per hectare for wheat and rice (paddy), respectively (FAO, 2004). Now maize has become an important cereal crop in Bangladesh. The area, production, and yield of wheat and maize from 1999-00 to 2005-06 are presented in Table 1. It is revealed from the table that area, production, and yield of wheat are decreasing in each year from 1999-00 to 2005-06, while it is increasing for maize in each year during the same period. Its position is $1^{\text {st }}$ among the cereals in terms of yield [(maize: $5.30 \mathrm{mt} / \mathrm{ha}$; wheat: $1.60 \mathrm{mt} / \mathrm{ha}$ and rice: $2.52 \mathrm{mt} / \mathrm{ha}$ ), BBS (2006)] but in terms of area and production, it ranks 3rd just after rice and wheat. Because of more nutritious status, it could be good source of nutrients for under nourished and mal-nourished population in Bangladesh. It is now widely used in the poultry farms as feed and also used for human consumption in roasted and fried form.

\footnotetext{
${ }^{1 \& 4}$ Scientific Officer and Chief Scientific Officer, Agricultural Economics Division, respectivety, ${ }^{2}$ Senior Scientific Officer (Agricultural Economics), Farm Division, and ${ }^{3}$ Principal Scientific Officer (Agricultural Economics), HRC, BARI, Gazipur, Bangladesh.
} 
Table 1. Area, production and yield of wheat and maize over the period from 19992000 to 2005-2006.

\begin{tabular}{c|l|l|l|l|l|c}
\hline \multirow{2}{*}{ Year } & \multicolumn{3}{c|}{ Wheat } & \multicolumn{3}{c}{ Maize } \\
\cline { 2 - 7 } & Area (ha) & $\begin{array}{c}\text { Production } \\
\text { (mt) }\end{array}$ & $\begin{array}{c}\text { Yield } \\
\text { (mt/ha) }\end{array}$ & Area (ha) & $\begin{array}{c}\text { Production } \\
\text { (mt) }\end{array}$ & $\begin{array}{c}\text { Yield } \\
\text { (mt/ha) }\end{array}$ \\
\hline $1999-00$ & 832000 & 1840000 & 2.21 & 3161 & 4075 & 1.29 \\
$2000-01$ & 772000 & 1673000 & 2.17 & 4901 & 10350 & 2.11 \\
$2001-02$ & 742000 & 1606000 & 2.16 & 19972 & 64335 & 3.22 \\
$2002-03$ & 706000 & 1507000 & 2.13 & 29059 & 117255 & 4.04 \\
$2003-04$ & 567000 & 1248000 & 2.20 & 50030 & 241460 & 4.83 \\
$2004-05$ & 558000 & 976000 & 1.75 & 66803 & 356280 & 5.33 \\
$2005-06$ & 481000 & 772000 & 1.60 & 98408 & 521525 & 5.30 \\
\hline
\end{tabular}

Source: BBS (2003, 2006)

Demand for maize is increasing day by day in the world as well as in Bangladesh due to its diversified uses. If the rigid food habit of Bangladeshis is to be diversified from rice to maize, it would probably be possible to reduce food shortage to a great extent. Because, it is a high yielding and low-cost crop compared to rice and wheat. So, comprehensible plan is needed to make the crop popular and sustainable.

Bangladesh is one of the developing countries of the world. Almost half of the people of this country are still below the poverty level in terms of calories intake (2122 k. cal/day/person). So, the policy makers of Bangladesh are facing problems to make policies regarding the solution of the problem of malnutrition. Thus, if maize can be adopted in the existing cropping pattern, the food deficiency and required nutritional intake of the low income-earning people can be overcome substantially. But the rate of adoption and sustainability of maize depends largely on its economic profitability. Since studies regarding economic profitability of maize are very few, this study will provide valuable information that may be useful both of different levels of GOs and NGOs policy makers for formulating appropriate policy for widespread cultivation of maize in Bangladesh. With this view in mind, the study was undertaken to know agronomic practices, input use, cost and return of maize cultivation as well as to fmd out constraints to its higher production.

\section{Materials and Method}

The study was conducted in four major maize growing districts, namely Chuadanga, Dinajpur, Bogra, and Lahnonirhat based on intensity of maize area. The selected four districts covered 61 percent of total maize areas of the country. 
At first, a list of all maize growers was collected from each area and then a total of 200 maize growers taking 50 from each area were selected randomly from the lists for the study. Data were collected from the sampled maize growers by survey method with the help of pre-tested interview schedule during 2006-2007. The collected data were summarized and analyzed by tabular methods using average, percentage, ratios, etc.

\section{Results and Discussion}

\section{Agronomic practices}

Ploughing: In the study areas, most of the farmers used power tiller for land preparation and a very little percent of farmers used country plough and tractor. They applied ploughing by 3 - 6 times. On an average, $45 \%$ farmers ploughed their maize plot 4 times, $29 \%$ farmers ploughed 5 times, 21\% farmers ploughed 6 times and 5\% farmers ploughed 3 times (Table 2).

Table 2. Dislribution of sampled farmers according to number of ploughings done.

\begin{tabular}{|c|c|c|c|c|c|}
\hline \multirow[t]{2}{*}{ Locations } & \multicolumn{5}{|c|}{ Number of ploughings used (\% of farmer) } \\
\hline & 3 & 4 & 5 & 6 & All \\
\hline Chuadanga & 12 & 50 & 30 & 06 & 100 \\
\hline Dinajpur & 08 & 64 & 22 & 06 & 100 \\
\hline Bogra & 0 & 06 & 32 & 62 & 100 \\
\hline Lalmonirhat & 0 & 60 & 30 & 10 & 100 \\
\hline All Areas & 05 & 45 & 29 & 21 & 100 \\
\hline
\end{tabular}

Variety: Various types of maize variety were used in the study areas. It is revealed in Table 3 that on an average, $49 \%$ farmers sowed $900 \mathrm{M}$ variety of maize and it followed NK 40 (19\%), Pacific 60 (19\%), Pacific 11(11\%) and Pacific 984 (2\%).

Table 3. Distribution of sampled farmers according to variety used .

\begin{tabular}{|c|c|c|c|c|c|c|}
\hline \multirow[t]{2}{*}{ Locations } & \multicolumn{6}{|c|}{ Variety used (\% of farmers) } \\
\hline & $900 \mathrm{M}$ & NK 40 & Pacific 11 & Pacific 60 & Pacific 984 & All \\
\hline Chuadanga & 42 & 20 & 06 & 24 & 8 & 100 \\
\hline Dinajpur & 48 & 48 & 02 & 02 & 0 & 100 \\
\hline Bogra & 46 & 02 & 02 & 50 & 0 & 100 \\
\hline Lalmonirhat & 60 & 06 & 34 & 0 & 0 & 100 \\
\hline All Areas & 49 & 19 & 11 & 19 & 2 & 100 \\
\hline
\end{tabular}


Sowing time: Farmers in the study areas started maize seed sowing on 3 weeks of October and it continued upto the last week of December. Sixty eight percent Chuadanga farmers sowed maize seed on 3rd week to 4th week of November, $64 \%$ Dinajpur farmers sowed maize seed on 2nd week to 3rd week of December, $70 \%$ Bogra farmers sowed during $3^{\text {rd }}$ week to 4 th week of October, $68 \%$ Lalmonirhat farmers sowed during 2nd week to 3rd week of December (Table 4). It is found that Chuadanga and Bogra farmers followed early sowing time and Dinajpur and Lalinonirhat farmers followed late sowing time.

Table 4. Distribution of sampled farmers according to sowing date.

\begin{tabular}{lllll|l|c}
\hline \multirow{2}{*}{ Sowing date } & \multicolumn{5}{c}{ Location (\% of farmer) } \\
\cline { 2 - 6 } & Chuadanga & Dinajpur & Bogra & Lahnonirhat & All Areas \\
\hline $3^{\text {rd }}$ week of October & 06 & 0 & 44 & 0 & 13 \\
$4^{\text {th }}$ week of October & 02 & 0 & 26 & 0 & 07 \\
$1^{\text {st }}$ week of November & 0 & 0 & 02 & 0 & 01 \\
$2^{\text {nd }}$ week of November & 20 & 0 & 20 & 0 & 10 \\
$3^{\text {rd }}$ week of November & 40 & 06 & 08 & 02 & 14 \\
$4^{\text {th }}$ week of November & 28 & 08 & 0 & 16 & 13 \\
$1^{\text {st }}$ week of December & 04 & 12 & 0 & 14 & 08 \\
$2^{\text {nd }}$ week of December & 0 & 34 & 0 & 34 & 17 \\
$3^{\text {rd }}$ week of December & 0 & 30 & 0 & 34 & 16 \\
$4^{\text {th }}$ week of December & 0 & 10 & 0 & 0 & 03 \\
All & 100 & 100 & 100 & 100 & 100 \\
\hline
\end{tabular}

Harvesting time: It was found in Table 5 that $80 \%$ Chuadanga farmers harvested maize on 2nd week to 4th week of April, 56\% Bogra farmers harvested on 3rd week to 4 th week of March, $62 \%$ Dinajpur farmers harvested on $3^{\text {rd }}$ week to 4 th week of May and $78 \%$ Lalmonirhat farmers harvested 4th week of May to 1 week of June.

Crop duration: The average crop duration of maize was found 157 days. The highest crop duration was also found in Lalmonirhat (168 days) followed by Dinajpur (163 days), Bogra (151 days), and Chuadanga (147 days) (Table 5). 
Table 5. Distributiøn of sampled farmers according to harvesting date and crop duration.

\begin{tabular}{l|llllll}
\hline \multirow{2}{*}{ Sowing date } & \multicolumn{5}{c}{ Location (\% of fanner) } \\
\cline { 2 - 6 } & Chuadanga & Dinajpur & Bogra & Lahnonirhat & All Areas \\
\hline $3^{\text {rd }}$ week of March & 08 & 02 & 30 & 0 & 10 \\
$4^{\text {th }}$ week of March & 08 & 0 & 26 & 0 & 9 \\
& & & & & \\
$1^{\text {st }}$ week of April & 0 & 02 & 10 & 0 & 3 \\
$2^{\text {nd }}$ week of April & 32 & 04 & 28 & 0 & 16 \\
$3^{\text {rd }}$ week of April & 12 & 0 & 06 & 0 & 4 \\
$4^{\text {th }}$ week of April & 36 & 02 & 0 & 0 & 10 \\
$2^{\text {nd }}$ week of May & 04 & 14 & 0 & 0 & 4 \\
$3^{\text {rd }}$ week of May & 0 & 32 & 0 & 12 & 11 \\
$4^{\text {th }}$ week of May & 0 & 30 & 0 & 56 & 22 \\
$1^{\text {st }}$ week of June & 0 & 10 & 0 & 22 & 8 \\
$2^{\text {nd }}$ week of June & 0 & 04 & 0 & 10 & 3 \\
\hline All & 100 & 100 & 100 & 100 & 100 \\
Crop duration (day) & 147 & 163 & 151 & 168 & 157 \\
\hline
\end{tabular}

\section{Inputs use}

Human labour was the most important input in the production of maize. Human labour was employed in land preparation, fertilizing, intercultural operations, irrigating, insecticide, and pesticide use, harvesting, and post-harvest activities. The average human labour used for producing maize was found 144 man-days/ha in which $46 \%$ was family supplied and $54 \%$ was hired labour (Table 6 ). The average mechanical power was Tk. 3062 per hectare in which $21 \%$ was home supplied and $79 \%$ was purchased. On an average, the quantity of maize seeds used by the farmers was $20.32 \mathrm{~kg} / \mathrm{ha}$. Manure is the most important source to increase organic matter in the soil. All the farmers of Dinajpur and Lalmonirhat used cowdung but few farmers in Bogra and Chuadanga used cowdung. The farmers used cowdung from own source. The average quantity of cowdung was $5.5 \mathrm{t} / \mathrm{ha}$. The highest $(9.2 \mathrm{t} / \mathrm{ha})$ use was found in Dinajpur area and lowest use was in Chuadanga area (3.2 t/ha). Farmers in the study areas used chemical fertilizers, namely urea, TSP, MP, gypsum, zinc sulphate, and borax. The average quantities of urea, TSP, MP, gypsum, zinc sulphate, and borax used in maize cultivation were found to be $464,144,113,89,8$, and $4 \mathrm{~kg}$ per hectare, respectively. Majority of the Bogra farmers used only mixed fertilizers instead of TSP and MP and it was $400 \mathrm{~kg} / \mathrm{ha}$. Some farmers in Lalmonirhat used lime 
amounting $346 \mathrm{~kg} / \mathrm{ha}$. The application of manures and fertilizers was varied among the areas as well as among the farmers.

Table 6. Per heetare use of inputs in maize production.

\begin{tabular}{lllllll}
\hline \multicolumn{1}{c}{ Items } & Chuadanga & Dinajpur & Bogra & Lalmonirhat & All Areas \\
\hline Human Labour(man-day): & & & & & \\
Own & 77 & 42 & 88 & 57 & $66(46)$ \\
Hired & 95 & 71 & 80 & 64 & $78(54)$ \\
Total & 172 & 113 & 168 & 121 & $144(100)$ \\
Mechanical cost (Tk): & & & & & \\
Own & 364 & 566 & 1147 & 538 & $654(21)$ \\
Hired & 2978 & 2080 & 2235 & 2338 & $2408(79)$ \\
Total & 3342 & 2646 & 3382 & 2876 & $3062(100)$ \\
Seed (kg) & 20.62 & 20.38 & 21.36 & 18.92 & 20.32 \\
Cow dung (ton)(Own) & 3.20 & 9.24 & 3.36 & 6.20 & 5.50 \\
Urea (kg) & 463 & 443 & 444 & 507 & 464 \\
TSP (kg) & 180 & 137 & 25 & 233 & 144 \\
MP(kg) & 84 & 110 & 27 & 229 & 113 \\
Mixed (kg) & 0 & 0 & 400 & 0 & 100 \\
Gypsum (kg) & 67 & 95 & 18 & 177 & 89 \\
Zinc(kg) & 12 & 5 & 2 & 12 & 8 \\
Borax (kg) & 0.35 & 5 & 2 & 10 & 4 \\
Lime (kg) & 0 & 0 & 0 & 346 & 87 \\
\hline
\end{tabular}

Figures in the parentheses indicate percent of total

\section{Profitability level of maize cultivation}

Cost: The cost of production was calculated on total cost, variable cost, and cash cost basis. Variable cost included the cost of human labour, mechanical power, seed, manure, fertilizers, insecticides, irrigation, and machine charge. Human labour cost was the major (25\%) among the total cost items. The average costs of maize production were Tk. 44197, Tk. 33195 and Tk. 24441 per hectare on total cost, variable cost, and cash cost basis, respectively (Table 7). Gross cost slightly varied among the areas. 
Table 7. Cost of production of maize (Tk/ha).

\begin{tabular}{|c|c|c|c|c|c|}
\hline Items & Chuadanga & Dinajpur & Bogra & Lalmonirhat & All Areas \\
\hline \multicolumn{6}{|l|}{ Human Labour: } \\
\hline Own & 5606 & 3406 & 6611 & 4584 & 5052 \\
\hline Hired & 6917 & 5759 & 6010 & 5148 & 5959 \\
\hline Total & 12523 & 9165 & 12621 & 9732 & 11010 \\
\hline \multicolumn{6}{|l|}{ Mechanical cost: } \\
\hline Own & 364 & 566 & 1147 & 538 & 654 \\
\hline Hired & 2978 & 2080 & 2235 & 2338 & 2408 \\
\hline Total & 3342 & 2646 & 3382 & 2876 & 3062 \\
\hline Seed (purchased) & 3174 & 3760 & 3060 & 3233 & 3307 \\
\hline Cowdung(Own) & 1258 & 3188 & 1170 & 2138 & 1939 \\
\hline Urea & 2821 & 2765 & 2774 & 3269 & 2907 \\
\hline TSP & 3283 & 2006 & 356 & 3474 & 2280 \\
\hline MP & 1224 & 1543 & 368 & 3405 & 1635 \\
\hline Mixed & 0 & 0 & 5161 & 0 & 1290 \\
\hline Gypsum & 288 & 359 & 83 & 698 & 357 \\
\hline Zinc & 879 & 254 & 96 & 680 & 477 \\
\hline Borax & 24 & 281 & 61 & 583 & 237 \\
\hline Lime & 0 & 0 & 0 & 867 & 217 \\
\hline Total fertilizers & 8519 & 7208 & 8899 & 12976 & 9401 \\
\hline Insecticide & 202 & 51 & 668 & 525 & 362 \\
\hline \multicolumn{6}{|l|}{ Irrigation: } \\
\hline Own & 874 & 1897 & 1064 & 606 & 1110 \\
\hline Hired & 2794 & 869 & 1575 & 2822 & 2015 \\
\hline Total & 3669 & 2766 & 2639 & 3428 & 3126 \\
\hline Machine cost & 760 & 839 & 1270 & 1093 & 991 \\
\hline Intt. on op. capital & 585 & 518 & 590 & 630 & 581 \\
\hline Landuse cost & 9880 & 13338 & 9319 & 9148 & 10421 \\
\hline \multicolumn{6}{|l|}{ Gross cost: } \\
\hline Total cost basis & 43912 & 43479 & 43618 & 45779 & 44197 \\
\hline Total variable cost & 33447 & 29623 & 33709 & 36001 & 33195 \\
\hline Cash cost basis & 25344 & 20566 & 23717 & 28135 & 2444 \\
\hline
\end{tabular}


Yield: The average yield was found 8.00 t/ha. The yield found in Bogra, Dinajpur, Chuadanga, and Lalmonirhat area was 8.40 t/ha, 7.99 t/ha, 7.69 t/ha, and $7.91 \mathrm{t} / \mathrm{ha}$, respectively. Moreover, the farmers obtained a large volume of stover. It was difficult to estimate its value because it was not sold in the market. Poor men collected it from the field without payment and used it as fuel. In some areas, rachises (cobs without grain) were sold in cash and the average return from it was Tk. 1145 per hectare (Table 8).

Return: The average gross return from grain and stover was Tk. 69773 per hectare, of which $98 \%$ was received from grain. The gross return received by the farmers of Bogra, Dinajpur, Chuadanga, and Lalmonirhat area was Tk. 75957/ha, Tk. 62282/ha, Tk. 76186/ha, and Tk. 64665/ha, respectively. The average gross margins on total variable cost and cash cost basis were Tk. 36578/ha and Tk. 45332/ha, respectively. Bogra and Chuadanga farmers received higher gross margin than that of Dinajpur and Lalmonirhat farmers in both total variable and cash cost basis. The average net return was Tk. 25575 per hectare. The net return of Bogra, Dinajpur, Chuadanga, and Lalmonirhat areas was Tk. 32339/ha, Tk. 18803/ha, Tk. 32274/ha, and Tk. 18886/ha, respectively. On an average, benefit cost ratios were found 1.58, 2.10, and 2.85 for total cost, variable cost, and cash cost basis, respectively, which represents that one taka invest in maize production provides returns Tk. 1.58 to Tk. 2.85 based on in different costs basis. The average return to labour was calculated at Tk. 253 per day on total cost basis, which is much higher than the existing per day wage rate of Tk. 80 (Table 8). The farmers in Chuadanga and Bogra received higher returns than that of Dinajpur and Lalmonirhat farmers. Because, they sold maize early and in early price was high.

Table 8. Yield, return and profitability of maize production.

\begin{tabular}{llllll|l}
\hline \multicolumn{1}{c}{ Items } & \multicolumn{1}{c}{ Chuadanga } & Dinajpur & Bogra & Lalmonirhat & All Areas \\
\hline Yield (t/ha): & 7.69 & 7.99 & 8.00 & 7.91 & 8.00 \\
Gross Return (Tk/ha): & & & & & \\
Grain & 76186 & 61105 & 74465 & 62756 & 68628 \\
Stover & 0 & 1177 & 1492 & 1909 & 1145 \\
Total & 76186 & 62282 & 75957 & 64665 & 69773 \\
Gross cost (Tk/ha): & & & & & \\
Total cost basis & 43912 & 43479 & 43618 & 45779 & 44197 \\
Total variable cost & 33447 & 29623 & 33709 & 36001 & 33195 \\
Cash cost basis & 25344 & 20566 & 23717 & 28135 & 24441 \\
Gross Margin(Tk/ha): & & & & & \\
Total variable cost & 42739 & 32659 & 42248 & 28664 & 36578 \\
Net return (Tk/ha & 32274 & 18803 & 32339 & 18886 & 25575 \\
$\begin{array}{l}\text { Benefit Cost Ratio: } \\
\text { Total cost basis }\end{array}$ & 1.73 & 1.43 & 1.74 & 1.41 & 1.58 \\
Total variable cost & 2.28 & 2.10 & 2.25 & 1.80 & 2.10 \\
Cash cost basis & 3.01 & 3.03 & 3.20 & 2.30 & 2.85 \\
$\begin{array}{l}\text { Returns to labour } \\
\text { (Tk/man-day) }\end{array}$ & & & & \\
Total cost basis & 260 & 248 & 268 & 237 & 253 \\
\hline
\end{tabular}




\section{Comparative economics of maize and wheat cultivation}

According to national statistics, it is revealed from the Table 1 that the area, production and yield of wheat are decreasing in each year from 1999-00 to 200506, while it is increasing for maize in each year during the same period. It is also revealed that the area and production of wheat were found to be decreasing (Hasan, 2006). Kabir et al. (2005) reported that gross margin and benefit cost ratio of wheat were Tk. 11063 per hectare and 1.67, respectively, while Tk. 21091 per hectare and 1.90 in case of maize, respectively. It is found here that the profitability of maize was higher compared to wheat.

\section{Constraints to maize production}

The maize farmers were asked to respond about the constraint of maize production. In this regard, more than one answer was given by the respondents. It is revealed from the Table 10 that lack of capital was the first ranked constraint to maize production. It followed by high price of TSP, low price of maize, high price of good seed, disturbance of bird, dog, and foxes, lack of space for maize drying, lack of good seed and lack of knowledge.

Table 10. Constraints to maize production.

\begin{tabular}{l|l|l|l|l|l}
\hline \multirow{2}{*}{ Constraints } & \multicolumn{5}{c}{ Rank Value } \\
\cline { 2 - 6 } & Chuadanga & Dinajpur & Bogra & Lalmonirhat & All Areas \\
\hline 1. High price of TSP & 2 & 1 & 5 & 2 & 2 \\
2. Lack of Capital & 4 & 1 & 3 & 1 & 1 \\
3. Low price of Maize & 0 & 3 & 2 & 2 & 3 \\
4. Lack of good seed & 3 & 0 & 0 & 0 & 7 \\
5. High price of good seed & 1 & 2 & 1 & 3 & 4 \\
6. Disturbance of Bird, Dog and & 0 & 4 & 4 & 0 & 5 \\
Foxes & & & & & \\
7. Lack of space for maize drying & 5 & 0 & 0 & 1 & 6 \\
8. Lack of knowledge & 0 & 0 & 0 & 4 & 8 \\
\hline
\end{tabular}

\section{Conclusions and Recommendations}

Maize is a highly profitable crop on the basis of its return to investment. Modem inputs and production technology can help the farmers to increase income through increased yield and improve their socio-economic conditions. Maize can help in improving the nutritional status of the rural people. Production of maize can increase the income and employment opportunities of the farmers due to its diversified uses. Lack of capital and high price of TSP were the main constraints to its production 
Since seed played a significant role on maize yield, so it should make improved seed available to the farmers at reasonable price through research institutions, DAE and other related GO/NGO institutions. Improved or hybrid maize production technologies should be available to the farmers by training through Government and Non-government Organization. In-depth economic study should be taken for development of maize.

\section{References}

BBS 2003. Yearbook of Agricultural Statistics of Bangladesh. Bangladesh Bureau of Statistics, Ministry of Planning, Government of the People's Republic of Bangladesh. Dhaka.

BBS 2006. Yearbook of Agricultural Statistics of Bangladesh. Bangladesh Bureau of Statistics, Ministry of Planning, Government of the People's Republic of Bangladesh, Dhaka.

FAO. 2004. Production Yearbook Vol. 57- 2003. FAO Statistics Series, No. 177, Food and Agricultural Organization of the United Nations. Rome, Italy.

Hasan, Md. Kamrul. 2006. Yield gap in wheat production: a perspective of farm specific efficiency in Bangladesh. Ph. D. dissertation, Department of Agricultural Economics, Bangladesh Agricultural University, Mymensingh 2202, Bangladesh.

Kabir, M. Jahangir, Md. Elahi Baksh and M.A. Sufian. 2005. Comparative economic analysis of wheat, maize and boro rice cultivation under light soil in northern Bangladesh. Annual report 2004-05, Wheat Research Centre, Bangladesh Agricultural Research Institute, Noshipur, Dinajpur-5 200. 